\title{
KRAKOWSKIE TOWARZYSTWO WSPARCIA BIEDNYCH CHŁOPCÓW STAROZAKONNYCH. STUDIUM Z DZIEJÓW OPIEKI NAD MŁODZIEŻĄ ŻYDOWSKĄ W AUTONOMICZNEJ GALICJI*
}

\author{
Alicja Maślak-Maciejewska \\ Uniwersytet Jagielloński w Krakowie
}

\begin{abstract}
ASSOCIATION FOR THE SUPPORT OF THE POOR JEWISH BOYS IN CRACOW: A STUDY IN THE HISTORY OF THE JEWISH YOUTH CARE IN THE AUTONOMOUS GALICIA
\end{abstract}

The article focuses on the history of the Association for the Support of the Poor Jewish Boys, which was founded in Cracow in 1867. The aim of this institution was to give Jewish boys from unprivileged families an opportunity to learn crafts. Acquiring a profession was supposed to help the boys in earning the material and financial stability in their future lives. During the period of Galician autonomy, approximately 500 boys learned a profession thanks to the association. The number of association members varied in the discussed period, usually oscillating around 300 (it reached the maximum of 420 members). The majority of the association members were Jews, but also Christians engaged in its activities, among them the city president Józef Dietl. The association was financed from membership dues, donations and subsidies of various kinds (e.g. from the City Council or Cracow Savings Bank), and thanks to lectures and balls organized in its support. The activities of this association gained support among the so-called progressive Jews, praying in the Tempel. The progressives entered the association's management board (and dominated it in some periods), many representatives of this group became regular members of this association and supported it financially. The association was supported also by the progressive preachers: Szymon Dankowicz, Samuel Landau and Ozjasz Thon. For many years Arnold Rapaport served as the head of the association and supported it financially. Currently we celebrate the 150th anniversary of the existence of this association (it was founded in 1867, its statute confirmed one year later), which might serve as a good opportunity to recall its activities.

Key words: charity, philanthropy, support of youth, social history, $19^{\text {th }}$ century, Cracow, Galicia, progressive Jews, Tempel.

Słowa kluczowe: organizacja charytatywna, filantropia, wsparcie młodzieży, historia społeczna, XIX wiek, Kraków, Galicja, Żydzi postępowi, synagoga Tempel.

${ }^{*}$ Niniejszy artykuł powstał dzięki funduszom przyznanym autorce w ramach Pobytu badawczego GEOP, realizowanego w Muzeum Historii Żydów Polskich i w Żydowskim Instytucie Historycznym 
Towarzystwo Wsparcia Biednych Chłopców Starozakonnych w Krakowie pod godłem „opiekujcie się synami ubogich” było jednym z dłużej i prężniej działających żydowskich stowarzyszeń dobroczynnych. Jego działalność trwała przez cały okres autonomii galicyjskiej i sięgała po dwudziestolecie międzywojenne. Celem Towarzystwa było zapewnienie chłopcom pochodzącym z ubogich rodzin żydowskich nauki konkretnego zawodu rzemieślniczego. Towarzystwo to jest ciekawym przykładem organizacji dobroczynnej, która stawiała sobie za cel opiekę nad młodzieżą, dążąc jednocześnie nie tyle do zapewnienia jej doraźnego wsparcia, ile pomocy długofalowej, która miała wykształcić w nich społeczną samodzielność. W dzieło to było zaangażowanych wielu wybitnych mieszkańców Krakowa, takich jak na przykład Arnold Rapaport, Jonatan Warschauer, Józef Oettinger, Szymon Dankowicz czy Józef Dietl.

Wzmianki bądź krótkie omówienia działalności tego towarzystwa znalazły się w kilku opracowaniach na temat dziejów krakowskiej gminy żydowskiej i opieki nad dzieckiem w Galicji² ${ }^{2}$ jednak jego dzieje nie doczekały się do dziś szerszego opracowania i obecnie pozostaje ono relatywnie słabo znane. Mijająca obecnie 150. rocznica powołania tej instytucji wydaje się dobrą okazją do przypomnienia jej działalności.

\section{CELE DZIAŁALNOŚCI I WYCHOWANKOWIE TOWARZYSTWA}

Towarzystwo Wsparcia Biednych Chłopców Starozakonnych zostało założone w 1867 roku, a jego statut został zatwierdzony przez c.k. Namiestnictwo rok później,

im. Emanuela Ringelbluma, w ramach Global Education Outreach Program, ufundowanym przez William K. Bowes Jr. Foundation, Taube Philanthropies i Stowarzyszenie Żydowski Instytut Historyczny. Odpowiedzialność za stwierdzenia i poglądy zawarte w publikacji ponosi wyłącznie autorka.

1 Taka nazwa stowarzyszenia podawana była w jego statucie i sprawozdaniach. W statucie podawano równolegle niemiecką nazwę Verein zur Unterstützung armer jüdischer Knaben. Stowarzyszenie działało pod godłem „opiekujcie się synami ubogich”, które jest częścią talmudycznego cytatu „hisaharu bibnej aniim szemihem taca tora”, czyli „opiekujcie się synami ubogich, bo z nich wyjdzie nauka”. Godło to w hebrajskim brzmieniu funkcjonowało często jako nazwa identyfikująca stowarzyszenie (np. Stowarzyszenie Hisaharu). W prasie i innych źródłach z epoki funkcjonowało równolegle kilka nazw zwyczajowych, np. Towarzystwo Opieki nad Zaniedbanymi Chłopcami Starozakonnymi, Stowarzyszenie Wsparcia Ubogich Chłopców Żydowskich. W niniejszym artykule dla ułatwienia nie podaję każdorazowo pełnej nazwy tego towarzystwa, posługuję się skrótowo nazwą „Towarzystwo” (zapis od wielkiej litery).

2 Najszerzej jego działalność omówiła H. Kozińska-Witt, która jednak ograniczyła się do pierwszych lat jego działalności, zob. H. Kozińska-Witt, Die Krakauer Jüdische Reformgemeinde 18641874, Peter Lang, Frankfurt am Main 1999, s. 157-159. Zob. też: A. Żbikowski, Żydzi krakowscy i ich gmina w latach 1869-1919, Wydawnictwo DiG, Warszawa 1994, s. 262; J. Meissner-Łozińska, Placówki opieki nad dzieckiem w Krakowie w okresie autonomii galicyjskiej [w:] Galicja i jej dziedzictwo, t. 16: Opieka nad dzieckiem w Galicji, red. A. Meissner, Wydawnictwo Uniwersytetu Rzeszowskiego, Rzeszów 2002, s. 112. 
14 kwietnia 1868 roku$^{3}$. W dokumencie tym w następujący sposób precyzowano cele jego działalności:

Zadaniem towarzystwa jest ułatwianie biednym chłopcom starozakonnym wykształcenia się w zawodzie rzemieślniczym, handlowym lub przemysłowym, lub też w zawodach innych, do których szczególne okażą uzdolnienie ${ }^{4}$.

Statut Towarzystwa precyzował, że jego działalność ograniczona będzie do dzieci płci męskiej; według zachowanych źródeł taki profil był utrzymany przez cały okres jego działalności i nie wspierało ono dziewczynek. Przyjętych chłopców kształcono poprzez skierowanie ich na naukę do konkretnych zakładów rzemieślniczych, handlowych i fabryk, gdzie pod okiem wyznaczonego i opłacanego przez Towarzystwo majstra mieli zgłębiać tajniki zawodu. Co istotne, w Towarzystwie kładziono duży nacisk na jakość i poziom tego wykształcenia, tak by - jak podkreślano - wychowankowie byli w stanie zdobyć samodzielność, a w przyszłości wytrzymać konkurencję rynkową, utrzymać się w zawodzie i wyżywić rodzinę. Jak pisano, chciano dzieci ,przygotowywać do walki o byt w ten sposób, by później bez niczyjej pomocy, lecz własną uczciwą pracą utrzymać się mogły"s. By móc osiągnąć ten cel, Towarzystwo starało się kierować uczniów do wiodących i doświadczonych majstrów. Taki model działania miał w zamierzeniach zarządu Towarzystwa skutecznie chronić pochodzących z bardzo ubogich rodzin wychowanków przed biedą w dorosłym życiu. Nauka zawodu była więc traktowana jako inwestycja w przyszłość, daleko wykraczająca poza wsparcie doraźne. Miała mieć wpływ na zapobieganie ubóstwu w przyszłości, a tym samym na przyszłą poprawę ogólnej sytuacji społeczeństwa żydowskiego. Analiza sprawozdań Towarzystwa pokazuje, że do najczęściej wybieranych profesji należały między innymi: krawiec, szewc, tapicer, czapnik, piekarz bądź cukiernik, blacharz, stolarz, ślusarz; nieco rzadziej chłopców przyuczano do zawodu szmuklerza, kufernika, zegarmistrza, fryzjera i złotnika. Pojedynczy chłopcy uczyli się zawodów kapelusznika czy malarza szyldów. Mimo deklaracji statutowych, że chłopcy będą kierowani zarówno do zawodów rzemieślniczych, jak i handlowych, te drugie prawie w ogóle nie występują. Do wyjątków należy praktyka w handlu towarów galanteryjnych i norymberskich ${ }^{6}$.

3 Zob. Central Archive for the History of Jewish People [dalej: CAHJP], sygn. HM2/8934.17, Statut Towarzystwa wsparcia biednych chłopców starozakonnych pod godtem „,Opiekujcie się synami ubogich”, Drukarnia Uniwersytetu Jagiellońskiego, Kraków 1868; statut przedrukowano kilkanaście lat później, z dodaniem jego brzmienia niemieckiego, zob. Statuten des , Vereines zur Unterstutzung armer judischer Knaben"/ Statuta Towarzystwa wsparcia biednych chłopców starozakonnych pod godtem „Opiekujcie się synami ubogich”, Nakładem towarzystwa. Czcionkami drukarni związkowej pod zarządem A. Szyjewskiego, Kraków 1881.

4 Ibidem.

5 Dwudzieste dziewiate sprawozdanie zarządu Stowarzyszenia wsparcia biednych chtopców starozakonnych pod godtem ,opiekujcie się synami ubogich” za czas od 1-go grudnia 1894 do 30-go listopada 1895, Nakładem Stowarzyszenia - Drukiem Józefa Fischera, Kraków 1895, s. 3.

6 Informacje te podaję za zachowanymi sprawozdaniami Towarzystwa; były one wydawane w formie osobnej broszury, zob. Sprawozdanie wydzialu zawiadowczego towarzystwa wsparcia biednych chłopców starozakonnych pod godtem ,opiekujcie się synami ubogich”, ,hisaharu bibne aniim " z zarzadu funduszów w roku od 1 grudnia 1870 do 1 grudnia 1871., W Drukarni Uniwersytetu Jagiellońskiego 
Poza nauką zawodu wychowankom zapewniano również bieżącą pomoc materialną. Obejmowała ona przede wszystkim zakup bielizny, obuwia i całorocznej odzieży, naprawę tychże, a także zakup przyborów szkolnych i narzędzi do pracy ${ }^{7}$. Analiza sprawozdań finansowych Towarzystwa pokazuje, że koszty zakupu odzieży, obuwia i bielizny stanowiły największy wydatek. Wśród wydatków Towarzystwa znajdujemy także pozycje związane z utrzymaniem higieny - kąpiele oraz strzyżenie włosów. Towarzystwo posiadało ponadto własnego lekarza, który czuwał nad zdrowiem wychowanków. Przynajmniej od początku XX wieku osieroceni chłopcy mogli mieszkać w utrzymywanym przez Towarzystwo schronisku ${ }^{8}$. Ze sprawozdań dowiadujemy się, że stanowili oni około jednej trzeciej ogólnej liczby wychowanków ${ }^{9}$.

Obok praktycznej nauki zawodu i wsparcia materialnego Towarzystwo realizowało także szerokie cele wychowawcze. Mimo iż w statucie jako cel istnienia organizacji wskazywano wyuczenie chłopców konkretnego zawodu, jego misję, przynajmniej od początku lat 70. XIX wieku, postrzegano szerzej - miało ono kształcić w chłopcach postawy obywatelskie. W zaproszeniu na bal charytatywny, jaki zorganizowano na rzecz Towarzystwa w 1871 roku, w następujący sposób charakteryzowano jego cele:

Towarzystwo wsparcia biednych chłopców starozakonnych, wziąwszy sobie za zadanie wychować i kształcić biedniejszą młodzież pozbawioną wszelkiej opieki, starało się, wszczepiając

pod zarządem K. Mańkowskiego, Kraków 1871; Sprawozdanie roczne zarządu towarzystwa wsparcia biednych chłopców starozakonnych pod godtem: „Opiekujcie się synami ubogich” za czas od 1 grudnia 1874 do 1 grudnia 1875, Nakładem Stowarzyszenia, Czcionkami drukarni „Czasu”, Kraków 1875; Dwudzieste trzecie sprawozdanie zarządu stowarzyszenia Wsparcia Biednych Chtopców Starozakonnych pod godtem „Opiekujcie się synami ubogich” za czas od 1 Grudnia 1888 do 1 Grudnia 1889, Nakładem Stowarzyszenia, Kraków 1889; Dwudzieste czwarte sprawozdanie zarządu Stowarzyszenia Wsparcia Biednych Chłopców Starozakonnych pod godtem „Opiekujcie się synami ubogich” za czas od 1 Grudnia do 30 Listopada 1890., Nakładem Stowarzyszenia, Kraków 1890; Dwudzieste piate sprawozdanie zarządu Stowarzyszenia wsparcia biednych chłopców starozakonnych pod godtem ,,opiekujcie się synami ubogich" za czas od 1-go Grudnia 1890 do 30-go Listopada 1891, Nakładem Stowarzyszenia - Drukiem Józefa Fischera, Kraków 1891; Dwudzieste siódme sprawozdanie zarządu Stowarzyszenia wsparcia biednych chtopców starozakonnych pod godtem ,opiekujcie się synami ubogich” za czas od 1-go Grudnia 1892 do 30-go Listopada 1893, Nakładem Stowarzyszenia - Drukiem Józefa Fischera, Kraków 1893; Dwudzieste ósme sprawozdanie zarząu Stowarzyszenia wsparcia biednych chtopców starozakonnych pod godtem ,opiekujcie się synami ubogich” za czas od 1-go Grudnia 1893 do 30-go Listopada 1894, Nakładem Stowarzyszenia - Drukiem Józefa Fischera, Kraków 1894; Dwudzieste dziewiąte sprawozdanie zarzadu Stowarzyszenia wsparcia biednych chtopców starozakonnych pod godtem „opiekujcie się synami ubogich" za czas od 1-go grudnia 1894 do 30-go listopada 1895...; Trzydzieste sprawozdanie zarzadu stowarzyszenia wsparcia biednych chtopców starozakonnych pod godtem ,opiekujcie się synami ubogich" za czas od 1-go grudnia 1895 do 30-go listopada 1896, Nakładem Stowarzyszenia - Drukiem Józefa Fischera, Kraków 1896; Trzydziesto-siódme sprawozdanie zarządu stowarzyszenia wsparcia biednych chtopców starozakonnych pod godłem ,opiekujcie się synami ubogich” za czas od 1-go stycznia 1903 do 31-go grudnia 1903, Nakładem Stowarzyszenia - Drukiem Józefa Fischera, Kraków 1904. W dalszej części artykułu referencję podaję skrótowo (np. Sprawozdanie 1871).

7 Zakupy te są szczegółowo notowane przez sprawozdania finansowe Towarzystwa.

8 „Sprawiedliwość” 1902, nr 5, s. 4.

9 Zob. Sprawozdanie 1903. 
w młode umysły pracę, miłość kraju i bogobojność, przysporzyć naszej ojczyźnie prawdziwych obywateli, ludzi pracy i użytecznych członków naszego społeczeństwa ${ }^{10}$.

Cele istnienia Towarzystwa były podobnie postrzegane przez opinię publiczną i w następujący sposób charakteryzowano je na łamach „Nowej Reformy”: „,eelem jest wykształcenie biednych chłopców starozakonnych na dobrych rzemieślników, a przytem wychowanie ich w języku i duchu ojczystym"11.

Obok edukacji zawodowej chłopcy otrzymywali także regularną edukację szkolną. Początkowo Towarzystwo zatrudniało nauczycieli, później chłopcy pobierali naukę w miejskiej szkole przemysłowej na Kazimierzu ${ }^{12}$. Warto zaznaczyć, że przykładało ono wagę do edukacji religijnej. Przez cały omawiany okres utrzymywało własnego nauczyciela religii ${ }^{13}$. Wśród wydatków Towarzystwa znajdujemy także takie pozycje, jak zakup modlitewników i filakterii dla chłopców.

Mimo że głównym celem Towarzystwa była nauka zawodu, udzielało ono także różnych form pomocy doraźnej. Przyjęty chłopiec właściwie przechodził więc na utrzymanie Towarzystwa, co przynosiło korzyści nie tylko jemu samemu, ale także w znacznym stopniu odciążało finansowo jego rodzinę. $Z$ jednego ze sprawozdań Towarzystwa dowiadujemy się, że wielu rodziców było zainteresowanych przyjęciem ich dziecka i że zainteresowanie to znacznie przekraczało możliwości finansowe tej organizacji $1^{14}$.

Dane liczbowe na temat liczby wychowanków Towarzystwa, którymi dysponujemy, są niestety wyrywkowe. Na podstawie zachowanych sprawozdań rocznych, prasy i innych źródeł możemy prześledzić je w ogólnym zarysie. Na samym początku swej działalności Towarzystwo było w stanie wesprzeć zaledwie sześciu chłopców ${ }^{15}$. W ciągu czterech lat liczba wychowanków zwiększyła się czterokrotnie (1871 24 chłopców). Nieco później, w ostatniej ćwierci XIX wieku, wahała się od 32 do 43. Liczbę 50 wychowanków przekroczono dopiero na początku kolejnego stulecia. $\mathrm{W}$ związku z tym, że nauka trwała dłużej niż rok i zaczynano ją w różnych okresach roku, podane wyżej dane - nawet gdy są dostępne dla kilku lat z rzędu - nie sumują się w prosty sposób. Jak się wydaje, dany chłopiec był notowany jako wychowanek Towarzystwa kilkakrotnie, przez cały czas pozostawania pod jego opieką. W sprawozdaniach zazwyczaj wskazywano na liczby uczniów pozostających w zakładzie

10 „Czas” R. XXIV: 1871, nr 32.

11 „Nowa Reforma” R. II: 1883, nr 295, s. 3.

12 Zob. Sprawozdanie 1871, 1874, 1878, gdzie wymieniane jest stanowisko nauczycieli w dwóch oddziałach, nauczyciela rysunku i religii; zob. Sprawozdanie 1889 i późniejsze, gdzie podawana jest informacja, że chłopcy uczęszczają do szkoły przemysłowej na Kazimierzu. Nawet jednak w tym okresie Towarzystwo utrzymywało własnego nauczyciela religii; por. H. Kozińska-Witt, Die Krakauer..., s. $158-159$.

13 Pierwsze sprawozdania niestety nie notują kto pełnił tę funkcję. Informacja ta pojawia się od połowy lat 90. XIX w. Wówczas na tym stanowisku pracował Szymon Seitner, zob. Sprawozdanie 1895; Sprawozdanie 1896. Na początku XX w. jako nauczyciel Towarzystwa pracował Maurycy Schapira, zob. Sprawozdanie 1903.

14 Sprawozdanie 1895.

15 „Sprawiedliwość” R. XI: 1903, nr 6; por. „Gazeta Polska” 1868, nr 35, s. 1, gdzie mowa jest o 15 chłopcach. 
na początku roku rozliczeniowego, nowych uczniów przyjętych w trakcie roku, chłopców wydalonych i takich, którzy sami zrezygnowali z nauki, a wreszcie absolwentów. W latach, dla których posiadamy dane, liczba absolwentów wahała się od 6 (1895) do 14 (1891), przeważnie oscylując koło 10. Jeśli te szczątkowo zachowane dane były reprezentacyjne dla całego okresu, to w ogromnym przybliżeniu możemy szacować, że w okresie autonomii Galicji ogólna liczba chłopców, którzy dzięki Towarzystwu zyskali konkretny zawód, mogła wynosić około pół tysiąca. W 1881 roku podczas obrad Sejmu Krajowego, dyskutując wysokość subwencji dla Towarzystwa, odwoływano się do faktu, że podczas 15 lat działalności wychowało ono „przeszło 200 młodzieńców izraelickich"16. W 1894 roku podawano na łamach prasy, że Towarzystwo podczas swojej 28-letniej działalności dało zawodową samodzielność więcej niż 300 chłopcom, co mogą potwierdzić przedstawione wyżej szacunki ${ }^{17}$.

\section{CZŁONKOWIE I ZARZĄD STOWARZYSZENIA}

W poszczególnych latach, dla których dysponujemy danymi, liczba członków Towarzystwa wynosiła od 264 do 420 . W początkowym okresie wahała się od około 380 do 420 członków $^{18}$. W 1883 roku liczyło ono 345 członków $^{19}$, zaś później, a więc od końca lat 80. do początku kolejnego stulecia, nie przekraczała 300 - wynosiła na przykład 283 osoby w 1889 roku, 264 w 1894 roku, 269 w 1895 roku i 284 w 1896 roku. W 1903 roku na łamach krakowskiego czasopisma „Sprawiedliwość” donoszono, że Towarzystwo liczy w bieżącym roku 256 członków i zestawiając te dane z ogólną liczbą Żydów w mieście (28 000) oraz liczbą kupców i przemysłowców żydowskich (2190), oceniano, że tak niska liczba członków ,jest w istocie wstydem i hańbą dla pospólstwa żydowskiego w naszem mieście" ${ }^{20}$. Niestety nie udało się odnaleźć danych na temat liczby członków Towarzystwa po 1903 roku, nie wiemy więc, jak kształtowało się jego społeczne poparcie. Dane dla wcześniejszego okresu pokazują jednak wyraźnie tendencję spadkową poparcia dla Towarzystwa, wyrażającą się w liczbie jego członków opłacających składki. W ostatnich dwóch dekadach XIX i na początku XX wieku jego liczebność spadła bowiem o około jedną czwartą względem wcześniejszego okresu. Mimo tego spadku sukcesywnie zwiększała się liczba chłopców, którym udzielono wsparcia (por. wyżej).

Warunkiem, który stawiano przyszłym członkom Towarzystwa, było regularne opłacanie comiesięcznych składek. Poza tym nie precyzowano w dodatkowy sposób,

16 „Gazeta Lwowska” R. LXXI: 1881, nr 223, s. 2.

17 „Sprawiedliwość” R. II: 1894, nr 2.

18 Już w październiku 1867 r., a więc w roku ukonstytuowania się Towarzystwa, liczba jego członków była szacowana na ponad 300, zob. „Die Neuzeit” R. VII: 1867, nr 41, s. 476; 420 członków liczyło Towarzystwo w 1871 r., zob. Sprawozdanie 1871; por. też H. Kozińska-Witt, Die Krakauer..., s. 159.

19 „Nowa Reforma” R. II: 1883, nr 295.

20 „Sprawiedliwość” R. XI: 1903, nr 6. 
na przykład odwołując się do kategorii płci czy wyznania, kto może wstąpić w jego szeregi. Analiza kilku zachowanych list członków pokazuje jednak, że w znakomitej większości (około 98\% członków) wstępowali do niego mężczyźni. Pierwsza lista członków, jaką posiadamy, pochodzi z 1889 roku i notuje zaledwie jedną kobietę („Pani Sloma - wdowa”) na 283 osoby. Kilka lat później na listach członków z 1894 i 1895 roku znalazły się cztery kobiety: P. Fragner, Ludwika Szancerowa, R. Wachtel i Amelié Quadratstein. Rok później dołączyły do nich Amalie Frankel i Rachela Holzer. Na ostatniej liście, z 1903 roku, nie podawano płci członków i część imion zapisywano jedynie za pomocą inicjału, stąd identyfikacja kobiet jest utrudniona. Na pewno jednak wśród członków Towarzystwa były przynajmniej dwie: Ludwika Szancer oraz Rachela Holzer. Tak mały udział kobiet wynikał z istniejącej wówczas praktyki, że w szeregi danego towarzystwa zazwyczaj wstępował mężczyzna, który niejako reprezentował w nim rodzinę. Po śmierci męża wdowa niekiedy podejmowała lub kontynuowała pracę $\mathrm{w}$ danym stowarzyszeniu i wówczas to ona należała do jego członków. Tak było na przykład w wypadku wspomnianej wyżej Ludwiki Szancer (ur. 1813) ${ }^{21}$, wdowy po lekarzu Leonie Szancerze (1802-1879) - była członkinią Towarzystwa Wsparcia Chłopców przynajmniej w latach 1894-1903, dla których posiadamy wykazy ${ }^{22}$. Kobiety, które tak rzadko same były członkiniami Towarzystwa, wspierały je jednak na inne sposoby, głównie finansowo. Znajdujemy je wśród darczyńców przekazujących datki niewynikające ze statutowych obowiązków członków Towarzystwa ${ }^{23}$ i wśród organizatorek bali na jego rzecz.

Statut Towarzystwa precyzował, że instytucją tą administrować będzie zarząd (określany w statucie jako „wydział zawiadowczy”) składający się z 15 osób i wybierany w głosowaniu tajnym podczas walnego zgromadzenia członków. Zarząd wybierany był raz na dwa lata, przy czym po pierwszym roku urzędowania występowało z niego siedem wytypowanych drogą losowania osób i na ich miejsce zarząd dobierał nowe ${ }^{24}$. Spośród siebie zarząd wybierał prezesa, dwóch wiceprezesów, sekretarza i kasjera. Skład tego ścisłego zarządu pozostawał na przestrzeni lat podobny. Pierwszym prezesem Towarzystwa został Arnold Rapaport i pozostawał on na tym stanowisku przez niemal trzy dekady, do 1895 roku, kiedy funkcję tę przejął Maurycy Wechsler (wcześniej będący wiceprezesem). Nawet jednak wówczas Rapaport

${ }^{21}$ Archiwum Narodowe w Krakowie [dalej ANKr], Akta spisu ludności miasta Krakowa z 1910 r., t. IV, poz. 738 .

22 Niestety niekompletność danych uniemożliwia stwierdzenie, czy Leon Szancer miał związki z Towarzystwem; więcej na jego temat i jego działalności dobroczynnej zob. M. Śliż, „Fundacja na stypendia dla biednych uczniów Wydziału Lekarskiego Akademii Jagiellońskiej bt. p. Leona Szancera" i jej twórca, „Archiwum Historii i Filozofii Medycyny” 2004, t. LXVII, nr 2-4, s. 139-149.

23 Były to następujące kobiety (stosuję napis zgodny ze źródłowym): Baczewska ze Szancerów, S. Jänner, Leonora Maerz (ku uczczeniu zmarłego ojca N. Steinberga), R. Holzer, Sara Wolfgang, Joanna Seinfeld, Anna Bauminger, Paulina Süsser, Drowa Kirschbaum, Berta Maschler z Tarnowa.

${ }^{24} \mathrm{Na}$ mocy art. 9 statutu zarząd miał prawo ponownie wybrać te same osoby; ze sprawozdań Towarzystwa wynika, że z możliwości tej korzystano. 
pozostawał prezesem honorowym. Wechsler piastował stanowisko prezesa do końca istnienia Towarzystwa ${ }^{25}$. Wszyscy członkowie zarządu funkcje swe pełnili honorowo.

\section{FINANSOWANIE I UTRZYMANIE TOWARZYSTWA}

Każdy członek Towarzystwa zobowiązany był do regularnego wpłacania na jego rzecz stałej opłaty miesięcznej. Dochody z tego tytułu stanowić miały główne źródło utrzymania Towarzystwa i są $\mathrm{w}$ jego statucie wymieniane jako pierwsze $\mathrm{w}$ punkcie dotyczącym źródeł dochodu. Pozostałe kategorie to składki dobrowolne, dochody z odczytów i zabaw publicznych organizowanych na rzecz Towarzystwa, a także odsetki $\mathrm{z}$ funduszu żelaznego ${ }^{26}$. Na przestrzeni lat rzeczywiście najważniejszym źródłem przychodu były składki, stopniowo wzrastały też wpływy z odsetek od funduszu żelaznego, których wysokość na początku XX wieku przekroczyła dochody ze składek. Istotną pozycję w budżecie stanowiły także regularne subwencje. Od pierwszych lat istnienia Towarzystwo było corocznie dotowane przez Gminę Miasta Krakowa subwencją wysokości 200 zł r., będąc tym samym jedną z pierwszych dobroczynnych instytucji żydowskich, która taką subwencję miejską otrzymywała ${ }^{27}$. W późniejszym okresie Towarzystwo było również wspierane subwencjami Krakowskiej Kasy Oszczędności ${ }^{28}$ oraz Izby Handlowej ${ }^{29}$. Na przełomie lat 80. i 90. otrzymało także bardzo wysokie subwencje od barona Hirscha. Dochody czerpało Towarzystwo także $\mathrm{z}$ różnego rodzaju indywidualnych datków, które wykraczały poza statutowe obowiązki finansowe członków. Ważną kategorią tych datków były legaty i sumy przekazywane na rzecz Towarzystwa w zapisach testamentowych. Zazwyczaj środki te były dołączane do funduszu żelaznego tej organizacji, która później korzystała z pochodzących od nich odsetek. Wśród osób, które podobnym zapisem wsparły Towarzystwo, znaleźli się między innymi Albert Rapaport, Abraham Gumplowicz, Jonatan Warschauer, Maurycy Silberstein, Salomon Natan Wechsler, Rozalia Löwenstein, Dawid Rosenzweig. Co roku do kasy Towarzystwa wpływała także pewna zmienna kwota pochodząca $\mathrm{z}$ dodatkowych, jednorazowych datków

${ }_{25}$ Zob. Aneks do niniejszego artykułu, w którym zestawiono, opierając się na sprawozdaniach, listę wszystkich członków zarządu Towarzystwa.

26 Zob. art. 7 statutu.

27 H. Kozińska-Witt, Miłosierdzie gminy? - niepublikowany tekst referatu wygłoszonego podczas międzynarodowej konferencji „Żydzi w Galicji/Jews in Galicia”, która odbyła się na Uniwersytecie Rzeszowskim w dniach 8-9 czerwca 2017. Dziękuję autorce za udostępnienie tekstu; należy jednocześnie zaznaczyć, że pierwsze zachowane sprawozdanie Towarzystwa z $1871 \mathrm{r}$. tej dotacji nie wymienia, pojawia się ona jednak we wszystkich późniejszych.

28 Zob. Sprawozdanie 1889; Sprawozdanie 1891; Sprawozdanie 1893; Sprawozdanie 1894; Sprawozdanie 1895; Sprawozdanie 1896; Sprawozdanie 1903; „Nowa Reforma” R. XXX: 1911, nr 338, s. 2; „Głos Narodu” R. II: 1894, nr 72, s. 5; „Ojczyzna” R. IX: 1889, nr 10; „Dziennik Poznański” R. XXXIV: 1892 , nr 134, s. 3.

29 Zob. Sprawozdanie 1893. 
przekazywanych przez członków i sympatyków tej instytucji. Kwoty te miały w poszczególnych latach różną wysokość i wahały się w okresach, dla których posiadamy sprawozdania, między $5 \%(1890,1903)$ a aż $25 \%$ (1871) rocznego przychodu, przy czym mediana tych wartości wynosiła $7 \%{ }^{30}$.

Na rzecz Towarzystwa organizowano także, ze zmienną regularnością, różnego rodzaju zbiórki, odczyty oraz bale dobroczynne. W źródłach zachowały się na przykład informacje o wygłoszeniu przez prezesa Towarzystwa, Arnolda Rapaporta, serii wykładów w Muzeum Przemysłowym w 1870 roku, z których dochód (38zł r.) został przeznaczony na rzecz Towarzystwa ${ }^{31}$. W 1894 roku wieczorek na rzecz Towarzystwa zorganizowała działająca w Krakowie Czytelnia Starozakonnej Młodzieży Handlowej - zebrane wówczas pieniądze (107 zł r.) stanowiły aż 6\% przychodu Towarzystwa na ten rok. Wydarzeniami, które służyły zarówno zbieraniu funduszy na rzecz Towarzystwa, jak i promocji jego ideałów, były zabawy i bale charytatywne. Pierwszy odbył się już w 1870 roku i został zorganizowany przez studenta prawa Z. Zinsa ${ }^{32}$. Także w kolejnych latach odbywały się podobne imprezy: w 1871 roku bal odbył się w domu Rapaporta przy Rynku nr 51, rok później w Hotelu Saskim; zorganizowana w 1877 roku zabawa odbyła się w sali Towarzystwa Strzeleckiego i została połączona z koncertem utworów Liszta, Beriota, Gounoda i Rubinstena oraz występem teatru amatorskiego, który odegrał sztukę Fredry pod tytułem Posażna jedynaczka ${ }^{33}$. W sali Towarzystwa Strzeleckiego bal zorganizowano także w 1879 roku. Również tę uroczystość uświetnił występ teatru amatorskiego, który wystawił dwie sztuki - komedię Fredry Pierwsza lepsza czyli nauka zbawienna oraz Qui pro quo Józefa Korzeniowskiego ${ }^{34}$. W 1895 roku Josef Siegel przeznaczył na rzecz Towarzystwa dochód ze sprzedaży swojej książki pod tytułem Moderne Wohlthätigkeit, w której zebrał teksty swoich odczytów wygłoszonych w krakowskiej loży Bnej Brith Solidarnośćs ${ }^{35}$.

\section{ZWOLENNICY I TWÓRCY TOWARZYSTWA}

Stosunek społeczeństwa żydowskiego do Towarzystwa Wsparcia Biednych Chłopców Starozakonnych nie był jednorodny. H. Kozińska-Witt zwracała uwagę na to, że wprawdzie część krakowskiej ortodoksji popierała jego utworzenie, ale postawa ta nie była powszechna - powołanie Towarzystwa skrytykował Szymon Schreiber, a także kręgi chasydzkie ${ }^{36}$. Środowiskiem, z którego wywodziło się wielu

\footnotetext{
30 Wyliczenie moje na podstawie zachowanych sprawozdań Towarzystwa.

31 Zob. Sprawozdanie 1871.

32 Ibidem. Zebrano wówczas $164 \mathrm{zł} \mathrm{r.}$

33 „Czas” R. XXX: 1877, nr 49, s. 2. Tam też szczegółowy opis przebiegu balu.

34 „Izraelita” [Warszawa] R. XIV: 1879, nr 13, s. 102.

35 J. Siegel, Moderne Wohlthätigkeit (Ausarbeitung eines im Winter 1893-94 im hiesigen Vereine „Solidarität” gehaltenen Vortrages), Druck von Josef Fischer, Krakau 1895.

36 H. Kozińska-Witt, Die Krakauer..., s. 157-158.
} 
sympatyków Towarzystwa, było tzw. środowisko Żydów postępowych ${ }^{37}$. Analiza składów zarządu Towarzystwa oraz list jego członków i darczyńców pokazuje, że miało ono bardzo silne związki z kręgami postępowymi. Środowisko to ukonstytuowało się w Krakowie w latach 40. XIX wieku (w 1843 roku został zatwierdzony pierwszy statut stowarzyszenia postępowego) ${ }^{38} \mathrm{i}$ za cel stawiało sobie spełnianie specyficznych potrzeb religijnych swoich członków oraz udzielanie wsparcia, zarówno członkom tego stowarzyszenia, jak i innym Żydom. Do stowarzyszenia postępowego należało wielu przedstawicieli żydowskiej inteligencji zawodowej, w tym osób, które odebrały świeckie wykształcenie na poziomie średnim (gimnazjalnym) i uniwersyteckim, a także kupców i przemysłowców. Środowisko to charakteryzowało się relatywnie dużym poziomem akulturacji i integracji z nieżydowskim społeczeństwem. Swoje potrzeby religijne spełniało najpierw w prywatnym domu modlitwy, a od 1861 roku we własnej synagodze (Tempel przy ul. Podbrzezie). Do synagogi tej wprowadzono bardzo umiarkowane reformy, głównie o charakterze estetycznym (większy nacisk na elegancję i decorum) i nowoczesne kazanie w języku niemieckim i polskim. W środowisku tym często odwoływano się do potrzeby „cywilizowania” i „unowocześnienia” społeczeństwa żydowskiego, co miało być osiągane głównie przez zmodernizowaną edukację. Samo środowisko postępowe postrzegało się przy tym jako elita, na której ciąży odpowiedzialność za resztę społeczeństwa żydowskiego. W światopogląd ten dobrze wpisały się ideały Towarzystwa Wsparcia Biednych Chłopców Starozakonnych, nastawionego na długofalową, nie zaś doraźną pomoc i upatrującego w wykształceniu klucza dla rozwiązania problemów społecznych (w tym przede wszystkim biedy). Wobec słabej dostępności bazy źródłowej trudno jest jednoznacznie przesądzić, czy idea powołania Towarzystwa wyszła z kręgów postępowych i na ile Towarzystwo było z tym środowiskiem związane w pierwszych latach swojej działalności ${ }^{39}$. W późniejszym jednak okresie związki te były bardzo silne, wielowymiarowe i niepodważalne. Zarówno wśród członków zwyczajnych Towarzystwa, jak i w jego zarządzie znajdujemy wielu postępowców. Postępowcy też w dużej mierze finansowali jego działalność jako darczyńcy.

Niewątpliwie duże znaczenie dla wzmocnienia znaczenia Towarzystwa i jego rozkwitu miało poparcie ideologiczne, jakiego udzielili mu duchowi liderzy społeczności postępowej, czyli kaznodzieje. Kaznodzieja był nowoczesnym typem przywódcy religijnego, którego rola znacznie wykraczała poza tradycyjną rolę rabina rozstrzygającego problemy halachiczne. Obok tradycyjnej formacji religijnej miał on także

37 Używając pojęć „Żydzi postępowi”, ,postępowcy” i „środowisko postępowe”, mam na myśli Żydów, którzy byli związani z tzw. stowarzyszeniem postępowym (nazwa tej organizacji zmieniała się kilkakrotnie w XIX w., ale stowarzyszenie to utrzymało ciągłość instytucjonalną; pierwsza nazwa brzmiała „Bet- und Unterstützungshauses der deutschen Israeliten”, później w użytku była nazwa „Stowarzyszenie Izraelitów Postępowych”). Określenia te są zgodne z autoidentyfikacją tej grupy i osób, które same siebie określały jako „postępowe”. Używając tych pojęć na potrzebę wydzielenia omawianej grupy, odżegnuję się jednak od konotacji wartościującej pozytywnie, jaka towarzyszyła użyciu tych określeń w XIX w.

38 Statut des Bet- und Unterstützungshauses der deutschen Israeliten in Krakau [1843], Druck von Karl Budweiser und Comp. in Krakau, Krakau 1857.

39 Niestety nie zachowały się listy członków Stowarzyszenia Postępowego z lat 60. XIX w. 
posiadać wykształcenie świeckie, akademickie (często na poziomie doktoratu). Do głównych zadań kaznodziei należało wygłaszanie kazań w języku narodowym (nowoczesnego typu, zawierających wskazania moralne, integrujących społeczność), ale także spełniał on funkcję przewodnika i lidera tej społeczności; oczekiwano, że jego działalność przyczyni się do „unowocześnienia” społeczności żydowskiej i otwarcia jej na wymogi współczesnego świata. Powołanie Towarzystwa zbiegło się w czasie z powierzeniem posady kaznodziejskiej w Templu Szymonowi Dankowiczowi (1834-1910). Dankowicz nie tylko wsparł Towarzystwo finansowo ${ }^{40}$, ale także wygłosił w 1868 roku kazanie na jego temat, które ukazało się drukiem w osobnej broszurze $^{41}$. W kazaniu tym, wygłoszonym już po zawiązaniu Towarzystwa, ale jeszcze przed zatwierdzeniem jego statutu, Dankowicz zdecydowanie poparł ideę założenia organizacji, a także kształcenia chłopców w praktycznych zawodach. Podkreślał, że wybór konkretnej profesji rzemieślniczej może być decyzją równie dobrą co tradycyjne poświęcenie się całodziennym studiom religijnym. Dankowicz nie dyskredytował tych studiów, jednak stwierdzał, że w wyborze drogi życiowej powinny być brane pod uwagę indywidualne predyspozycje i preferencje (,skłonności i usposobienie”) chłopca. Jego zdaniem nie należało naciskać na chłopca, by wybrał ścieżkę studiów religijnych. Mimo iż studia te były bardzo istotne i w pewnym zakresie każdy - zdaniem Dankowicza - powinien się im poświęcać, wyłączne skupienie się na nich powinno być zarezerwowane dla chłopców najzdolniejszych, a ponadto posiadających korzystną sytuację materialną. Dążenie do tego, by wszyscy chłopcy poświęcali się zaawansowanym studiom religijnym, uznał Dankowicz za model niekorzystny ze społecznego punktu widzenia:

Dopókiż bowiem ma jeszcze trwać spaczony kierunek wychowania wśród ludu naszego; spaczony, bo jednostronny, bo nienaturalny!? Dopókiż wychowanie naszej młodzi ma być tak kierowanem, jak gdyby wszyscy młodzieńcy w Izraelu byli uposażeni jednakowymi zdolnościami i skłonnościami? Jak gdyby wszyscy młodzieńcy w Izraelu wyłącznie tylko Rabinami i uczonymi archeologami stać się mieli? ${ }^{42}$

Kaznodzieja doceniał Towarzystwo Wsparcia Biednych Chłopców Starozakonnych za to, że dowartościowywało zróżnicowany model kształcenia młodzieży, czym przyczyniało się do walki z ubóstwem i wykluczeniem oraz do ogólnej poprawy sytuacji społeczności żydowskiej. Jego zdaniem działalność Towarzystwa mogła się także przyczynić do poprawy wizerunku Żydów w społeczeństwie nieżydowskim i do walki ze stereotypem, że Żydzi „pożytku krajowi nie przysparzają”³. Dankowicz nawoływał wszystkich Żydów, niezależnie od ich wieku, płci i statusu majątkowego, do wsparcia Towarzystwa wedle ich możliwości i zasobów, jakimi dysponują - albo

40 Zob. Sprawozdanie 1871.

41 S. Dankowicz, Boża Dań. Kazanie miane w sobotę parszas Wajakkel - Pekidej dnia 21 marca 1868 w synagodze na Podbrzeziu w Krakowie przez Szymona Dankowicza, magistra nauk filologiczno-historycznych, kaznodzieję zboru izraelickiego w Krakowie, Kraków 1868.

42 Ibidem, s. 6-7.

43 Ibidem, s. 13. 
finansowo, albo w przypadku braku takiej możliwości doświadczeniem, rozumem, radą, dobrymi chęciami, czasem i siłami ${ }^{44}$.

Poparcia Towarzystwu udzielili także inni kaznodzieje związani w późniejszym okresie z synagogą postępową. Brak wykazów członków Towarzystwa z okresu, gdy kaznodzieją był Maurycy Duschak (1815-1890; w Krakowie 1877-1888), bezpośredni następca Dankowicza na tym stanowisku, uniemożliwia stwierdzenie, czy angażował się on w prace Towarzystwa. Na pewno jednak wsparcia udzielił następca Duschaka, Samuel Landau, który przynajmniej w roku administracyjnym 1892/1893 wchodził w skład jego zarządu ${ }^{45}$, a później wspierał je jako jego członek zwyczajny ${ }^{46}$. W skład zarządu Towarzystwa wchodził także Ozjasz Thon, który był związany z krakowskim Templem od 1897 roku $^{47}$. Wsparcie, jakiego udzielili kaznodzieje, z pewnością wpływało na zwiększenie w środowisku postępowym rozpoznawalności Towarzystwa i na wzmożenie zainteresowania jego działalnością.

Niepełność bazy źródłowej uniemożliwia niestety procentowe oszacowanie liczby Żydów postępowych wśród członków Towarzystwa ${ }^{48}-\mathrm{w}$ poszczególnych latach należało do niego jednak przynajmniej po kilkadziesiąt osób, które możemy dziś jednoznacznie zidentyfikować jako postępowców. Jeśli weźmiemy pod uwagę, że wielkość środowiska postępowego wynosiła kilka procent ogółu społeczności żydowskiej Krakowa, udział tego środowiska w pracach Towarzystwa wydaje się tym wyraźniejszy. Wpływ ten widać szczególnie dobrze na przykładzie składu jego zarządu. Od połowy lat 70. XIX wieku przynajmniej jedna trzecia zarządu rekrutowała się spośród postępowców (A. Rapaport, J.A. Propper, M. Wechsler, H. Markusfeld, H. Aszkenazy, I.S. Herzog, J. Judkiewicz) ${ }^{49}$ i zaczęli oni pełnić kluczowe funkcje (takie jak prezes i wiceprezesi, skarbnik i sekretarz) w Towarzystwie. W 1878 roku trzy na pięć osób pełniących najważniejsze funkcje bez wątpienia należało do stowarzyszenia postępowego: A. Rapaport (prezes), H. Markusfeld (wiceprezes), M. Schönfeld (skarbnik). Pod koniec lat 80. XIX wieku udział postępowców we władzach Towarzystwa wynosił już przynajmniej dwie trzecie, przy czym cztery na pięć osób pełniących kluczowe funkcje należało do stowarzyszenia postępowego ${ }^{50}$. Taki stan utrzymał się w kolejnych latach.

Wielu przedstawicieli środowiska postępowego znajdujemy także na listach darczyńców Towarzystwa - wśród tych, którzy przekazali mu zapisy testamentowe

44 Ibidem, s. 15.

45 Zob. Sprawozdanie 1893, s. 4.

46 Zob. Sprawozdanie 1895, s. 11; Sprawozdanie 1896, s. 7.

47 Zob. Sprawozdanie 1904, s. 5.

48 Ta niepełność bazy źródłowej dotyczy zarówno dokumentacji związanej z Towarzystwem, jak i z samym środowiskiem postępowym.

49 Najwcześniejsza lista członków stowarzyszenia postępowego pochodzi dopiero z połowy lat 80 . XIX w. Z konieczności robię tutaj założenie, że przynależność do stowarzyszenia postępowego w przyszłości wiązała się z prawdopodobieństwem, że dana osoba należała do niego także wcześniej. Niewykluczone, że także inni członkowie zarządu, poza siedmioma wymienionymi, byli związani ze stowarzyszeniem postępowym.

50 Byli to A. Rapaport - prezes, M. Wechsler - wiceprezes, E. Tilles - sekretarz, A. Wechsler skarbnik. 
(np. A. Gumplowicz, S.N. Wechsler, J. Warschauer i inni) lub inne datki okolicznościowe (np. Józef Rosenblatt, Leopold Reich, Juliusz Przeworski, Zygmunt Szancer, Józef Kaufman, Leon Horowitz, Juliusz Epstein i wielu innych) ${ }^{51}$, a także wśród osób, które w inny sposób działały na jego rzecz. Do takich osób należał na przykład Izydor Jurowicz, który od lat 80. XIX wieku pełnił honorowo funkcję lekarza Towarzystwa. Czołowych działaczy środowiska postępowego znajdujemy ponadto w komitetach organizujących bale dobroczynne na jego rzecz - dla przykładu w komitecie organizacyjnym i wśród gospodarzy balu z 1871 roku znalazło się bardzo aktywne w kręgach postępowych małżeństwo Oettingerów - Amalia i Józef ${ }^{52}$. Także w późniejszych latach komitety organizacyjne miały w swoich szeregach wybitnych działaczy tego środowiska.

Poparcie postępowców i ich aktywność w Towarzystwie Wsparcia Biednych Chłopców Starozakonnych utrzymywało się przez cały badany okres. Działania propagujące działalność tej instytucji, takie jak zbiórki i bale dobroczynne, a także wsparcie tej inicjatywy przez najważniejszych liderów społeczności postępowej, zarówno świeckich, jak i kaznodziejów, przyczyniały się do wzrostu w środowisku postępowym świadomości istnienia Towarzystwa. Ciekawym źródłem, które może to potwierdzać, jest dokumentacja (zeznania świadków) dotycząca spisywania testamentu Maurycego Silbersteina, przedstawiciela środowiska postępowego. Silberstein zażądał wezwania notariusza i spisania testamentu, gdy znajdował się już na łożu śmierci (zmarł chwilę po przedstawieniu swojej ostatniej woli). W testamencie przekazał dużą część majątku żonie, powołał do życia fundację swojego imienia, resztę pieniędzy rozdysponował - jak można wnioskować na podstawie zeznań świadków - bez wcześniejszego dokładnego przemyślenia tej decyzji. Symptomatyczne jest to, że jedną z organizacji, która jako pierwsza przyszła mu na myśl, było Towarzystwo Wsparcia Biednych Chłopców Starozakonnych ${ }^{53}$.

Od pierwszych lat działalności Towarzystwo otrzymywało wsparcie także ze strony społeczeństwa chrześcijańskiego ${ }^{54}$. Co istotne, swoje poparcie dla Towarzystwa wyrazili prezydent i wiceprezydent miasta, Józef Dietl oraz Feliks Szlachtowski, uczestnicząc w balu wydanym na jego rzecz ${ }^{55}$. Dietl przekazał ponadto Towarzystwu datki finansowe ${ }^{56}$. Wśród chrześcijan, którzy wsparli Towarzystwo finansowo, znaleźli się także między innymi Ludwik Helcel, Adam Potocki ${ }^{57}$ i hr. Stanisław

51 Lista na podstawie dostępnych sprawozdań Towarzystwa.

52 „Czas” R. XXIV: 1871, nr 32.

53 CAHJP, sygn. HM3/942.1.

${ }^{54}$ W ciekawy sposób odniósł się do tego w kronice zagranicznej warszawski „Izraelita”: „O ile instytucja ta [Towarzystwo Wsparcia Biednych Chłopców Starozakonnych], ze wszechmiar użyteczna i wszędzie naśladowania godna, cieszy się ogólnym uznaniem, pokazuje ta okoliczność, że i obywatele chrześcijańscy zasilają ją hojnymi ofiarami”, w notce tej podawano też informację, że do kasy Towarzystwa wpłynęło z tego źródła 2000 fl., zob. „Izraelita” R. XI: 1876, nr 8.

55 Więcej na ten temat zob. H. Kozińska Witt, Die Krakauer..., s. 160.

56 Sprawozdanie 1871; Sprawozdanie 1878.

57 „Gazeta Polska” 1868, nr 35, s. 1. 
Mieroszewski. Mieroszewski, w uznaniu jego zasług na rzecz Towarzystwa, otrzymał zresztą tytuł jego członka honorowego ${ }^{58}$.

\section{ZAKOŃCZENIE}

Twórcy Towarzystwa Wsparcia Biednych Chłopców Starozakonnych bardzo szeroko postrzegali jego wpływ społeczny. To w działalności tej instytucji upatrywali spadku przestępczości na Kazimierzu. Niemal trzy dekady po zainicjowaniu prac Towarzystwa w następujący sposób pisali o jego zasługach:

Nie mamy zamiaru [...] czynów stowarzyszenia tego na tem miejscu uświetniać, a jednak niedawne to czasy, kiedy chłop lub kobieta swojego towaru bezpiecznie po Kazimierzu przewozić nie mogli, bo im zagrażały napady młodych włóczęgów. Wyrostki te zostałyby z pewnością plagą i hańbą żydowskiego społeczeństwa, gdyby ich stowarzyszenie to pod opiekę swą nie było wzięło, któremu w samej rzeczy mają do zawdzięczenia, jeżeli obecnie wyrośli na porządnych rzemieślników, którzy bądź w kraju, bądź za granicą uczciwie pracują i siebie i rodzinę swoją godziwie wyżywić są w stanie ${ }^{59}$.

Opis ten zawiera zapewne sporo przesady. Opisywane Towarzystwo stało jednak w szeregu innych działających w Krakowie organizacji, które za cel stawiały sobie wsparcie żydowskich dzieci i młodzieży pochodzących z nieuprzywilejowanych środowisk. Ich łączny wpływ mógł być rzeczywiście odczuwalny na krakowskim Kazimierzu. Jak zostało wyżej wspomniane, wielu członków i znakomita większość czołowych działaczy Towarzystwa wywodziła się z tzw. środowiska Żydów postępowych. Działalność dobroczynna tego środowiska w szczególny sposób kierowana była do dzieci i młodzieży. Wśród stworzonych bądź wspieranych przez nie stowarzyszeń wymienić możemy na przykład założone w 1877 roku Stowarzyszenie Wsparcia Biednych Uczniów Wyznania Mojżeszowego, które zapewniało ubogim uczniom uczącym się w kazimierskich szkołach ubrania, obuwie i książki szkolne, Bezpłatną Kuchnię dla Dziatwy Szkolnej bez Różnicy Płci i Wyznania, a także organizowane od lat 90. XIX wieku w Rabce kolonie letnie. Instytucje te wychodziły poza tradycyjnie pojętą cedakę. Ich cechą wspólną było przekonanie o potrzebie inwestycji w młode pokolenie, przede wszystkim w sferze edukacji (z naciskiem na świecką), ale także zdrowia i higieny. Starano się przy tym przekazywać pomoc, która nie ograniczy się jedynie do doraźnego wsparcia. Skupienie pomocy na młodym pokoleniu miało prowadzić do ogólnej poprawy położenia społeczeństwa żydowskiego i jego lepszej integracji ze społeczeństwem nieżydowskim.

Dalszych badań wymagają obecnie dzieje Towarzystwa w okresie międzywojennym. W pierwotnej formie organizacyjnej przestało ono z pewnością działać

58 Dział Rękopisów Biblioteki Jagiellońskiej, sygn. 9679: „Nominacje i dyplomy przyznane Stanisławowi hrabi Mieroszewskiemu, 1887” oraz materiały do jego działalności naukowej, społecznej i charytatywnej, k. 121-122.

59 Zob. Sprawozdanie 1895. 
przed końcem lat 20. XX wieku, a być może wcześniej ${ }^{60}$. Należy jednocześnie zaznaczyć, że jego działalność mogła zostać częściowo zastępowana bądź uzupełniana przez inne Towarzystwa i organizacje o podobnym profilu. Już w 1889 roku powstał w Krakowie pod auspicjami Izraelitische Allianz zu Wien Zakład dla Osieroconych Chłopców, w którym wychowankowie mieli się uczyć praktycznych rzemiosł, a przy okazji zyskiwać biegłość w języku polskim i kształcić w sobie postawy narodowe, obywatelskie i patriotyczne. Symptomatyczne jest to, że fundatorem budynku tej szkoły, który stanął przy ul. Starowiślnej, był wieloletni prezes Towarzystwa Wsparcia Biednych Chłopców Strozakonnych, Arnold Rapaport. W czasie otwarcia Zakładu Rapaport nawiązał zresztą do trwającej wówczas już od nieco ponad dwóch dekad działalności Towarzystwa, zaznaczając, że „od przeszło lat 20 datują się starania około skierowania żydowskiej młodzieży do rękodzieł" ${ }^{1}$. Działania te jednak okazały się, jak zaznaczał, niewystarczające wobec wzrastającego zubożenia społeczeństwa. Mimo podobnych celów (nauka rzemiosła, cele wychowawcze, kształtowanie postaw obywatelskich), Zakład miał nieco inny profil niż Towarzystwo, skierowany był bowiem wyłącznie do chłopców osieroconych. Znacznie mniejsze było też spektrum zawodów, których można było się uczyć - początkowo nauczano jedynie ślusarstwa i stolarstwa, później dołączono do nich również tokarstwo i snycerstwo ${ }^{62}$. Obie instytucje - Zakład i Towarzystwo - nawiązały zapewne jakąś formę współpracy ${ }^{63}$.

W okresie międzywojennym w Krakowie działała bursa żydowskich sierot rękodzielniczych, która mogła być kontynuacją prac Towarzystwa Wsparcia Biednych Chłopców Starozakonnych ${ }^{64}$. Działała bowiem pod tym samym godłem „Hisaharu Bibnej Anijim"65. Jak zostało wyżej wspomniane, już na przełomie XIX i XX wieku Towarzystwo wynajmowało lokal, w którym mogła mieszkać część chłopców (osieroconych, którzy byli beneficjentami Towarzystwa równolegle do chłopców pochodzących z ubogich rodzin), a później czyniło starania, by zakupić własny lokal. Stworzenie bursy mogło być zwieńczeniem tych starań. Sama bursa przyznawała się do długiej tradycji swojej działalności, sięgającej lat 60. XIX wieku ${ }^{66}$.

60 Pod koniec 1929 r. pytanie o istnienie Towarzystwa wysłało na ręce ostatniego prezesa, Maurycego Wechslera, Starostwo Grodzkie Krakowskie. Wówczas Towarzystwo już nie istniało, zob. ANKr, Starostwo Grodzkie Krakowskie, sygn. 246, „Opiekujcie się synami ubogich”. Towarzystwo wsparcia biednych chłopców starozakonnych 1929.

${ }_{61}$ „Ojczyzna” R. IX: 1889, nr 13.

62 „Ojczyzna” R. XI: 1891, nr 23.

63 Pisze o tym, jednak bez podania źródła, A. Żbikowski, op. cit., s. 262.

${ }^{64}$ Przypuszczenie, że początki bursy wiążą się z Towarzystwem Wsparcia Biednych Chłopców Starozakonnych, pojawia się w literaturze przedmiotu, zob. M. Ła ot, Opieka nad żydowskim dzieckiem sierocym w Małopolsce Zachodniej w okresie międzywojennym, „Prace Naukowe Akademii Jana Długosza. Pedagogika" 2005, nr 14, s. 68.

${ }_{65}$ Zob. np. „Nowy Dziennik” R. XXI: 1938, nr 49, s. 20.

66 Informację, że bursa działa od „przeszło 70 lat”, podawano w: Sprawozdanie z działalności Zachodnio-Małopolskiego Zwiazku Towarzystw Opieki nad Sierotami Żydowskimi w Krakowie. Czerwiec 1933, Kraków 1933, s. 16 [dalej Sprawozdanie 1933]; por. też „Nowy Dziennik” R. XVI: 1933, nr 161, s. 13, na łamach którego ogłaszano „zbiórkę na najstarszą instytucję w Krakowie” i podawano 
Podopieczni bursy, która mieściła się przy ul. Krakowskiej 53, uczyli się u prywatnych majstrów zawodów rzemieślniczych (spektrum profesji było szerokie, podobnie do wcześniejszego okresu ${ }^{67}$, uczęszczali do szkół wieczorowych i brali udział w lekcjach i pogadankach organizowanych dla nich w samej bursie ${ }^{68}$. Swoją opieką objęła ona także chłopców pochodzących spoza Krakowa. Prezesem bursy był Rafał Landau, zaś na stanowiskach wiceprezesów pracowali Izydor Landau oraz Matylda Schenkerowa, która była określana jako jej „dusza i motor”. Bursa kontynuowała działalność jeszcze w czasie II wojny światowej. Jej siedziba znajdowała się wówczas przy ul. Józefińskiej ${ }^{69}$.

\section{ANEKS: CZŁONKOWIE ZARZAZDU TOWARZYSTWA OD CZASU JEGO POWSTANIA DO POCZĄTKU XX WIEKU (W KOLEJNOŚCI ALFABETYCZNEJ) $)^{70}$}

\author{
Apter Wilhelm \\ Aschkenasy Hermann \\ Benenfeld Ł./Lasar \\ Birnbaum Juda \\ Dallet S.B. \\ Deiches J. \\ Deiches Salomon \\ Eichhorn Lazar (Łazarz) \\ Ehrenpreis Max. \\ Epstein Jul. \\ Feiwel \\ Fränkel Os.A.
}

\author{
Ginzig Abraham \\ Goldgart N. \\ Goldwasser Józef \\ Goldwasser Samuel \\ Goldwerth B. \\ Grünzweig Salomon \\ Gronner A.H. \\ Heidenfeld Józef \\ Herzog L.S. \\ Herzog J.S. \\ Himmelblau Fabian \\ Hoffman Leon
}

informację, że instytucja ta działa od przeszło 80 lat, wychowując „całe kadry najbiedniejszej młodzieży żydowskiej na pożytecznych członków społeczeństwa”.

67 Chłopcy uczyli się m.in. krawiectwa, kuśnierstwa, złotnictwa, parasolnictwa, elektrotechnictwa i techniki dentystycznej, zob. „Przegląd społeczny. Miesięcznik poświęcony zagadnieniom pracy społecznej i opieki nad dzieckiem” R. VII: 1933, nr 4-5, s. 101; zob. też Sprawozdanie 1933; „Nowy Dziennik" R. XVI: 1933, nr 121, s. 12.

68 Działalność bursy jest szczegółowo omówiona w: Sprawozdanie 1933. Źródło to było szeroko wykorzystywane w nowszej literaturze przedmiotu i stało się podstawą wiedzy o bursie, zob. M. Łapot, op. cit., s. 69; M. Szczy gieł, Formy opieki nad sierotami żydowskimi w Rzeczypospolitej Polskiej w latach 1918-1939 (wybrane przyklady i aspekty), „Prace Naukowe Akademii Jana Długosza. Pedagogika” 2005, nr 15, s. 183-184.

69 A. Biberstein, Zagłada Żydów w Krakowie, Wydawnictwo Literackie, Kraków 2001, s. 248 250.

70 Lista sporządzona na podstawie: „Nowa Reforma” 1883, nr 295; „Sprawiedliwość” R. XI: 1903, nr 6, oraz zachowanych sprawozdań Towarzystwa; uwzględniono też informacje na temat pierwszych zarządów Towarzystwa z okresu 1868-1874 podawane przez H. Kozińską-Witt, Die Krakauer..., s. 157-158. 
Hoffmann Leopold

Holländer Hirsch

Horowitz Max.

Horowitz Sal.

Jener Math.

Jennes Wolf

Judkiewicz J.D.

Klein M.

Kirsch Alex.

Landau Hirsch

Landau Samuel (kaznodzieja)

Landau Pinkus

Lebenbeim/Lebenheim Aleksander

Lebenheim Samuel

Leser Leon

Liebling Maurycy

Luchs (Luks) Zygmunt

Markusfeld Henryk

Mirtenbaum Emanuel

Pam (Pamm) Mendel

Pamm S.

Pamm F.
Propper Albert

Rapaport de Porada Arnold

Rabinowicz

Rosenberg Ludwik

Rosenblatt Józef

Rosenthal Israel

Schiff

Schmelkes F.

Schmelkes S. ${ }^{71}$

Schönfeld M.

Schrager Nachman

Siódmak Leon

Spira Benjamin

Spira Josua

Thieberg Natan

Tilles Emanuel

Thon Ozjasz

Wasserberg Norbert

Wechsler Adolf

Wechsler Maurycy

Weindling Joachim

\section{BIBLIOGRAFIA}

\section{Źródła archiwalne}

Archiwum Narodowe w Krakowie (ANKr)

Akta spisu ludności miasta Krakowa z 1910

Starostwo Grodzkie w Krakowie

Central Archive for the History of Jewish People, Jerozolima (CAHJP) HM2/8934.17

Dział Rękopisów Biblioteki Jagiellońskiej syg. 9679

\section{Źródła drukowane}

Dankowicz S., Boża Dań. Kazanie miane w sobotę parszas Wajakkel - Pekidej dnia 21 marca 1868 w synagodze na Podbrzeziu w Krakowie przez Szymona Dankowicza,

${ }^{71}$ Był członkiem zarządu w 1869 r.; zbieżność z nazwiskiem późniejszego postępowego kaznodziei przypadkowa. 
magistra nauk filologiczno-historycznych, kaznodzieję zboru izraelickiego w Krakowie, Kraków 1868.

Siegel J., Moderne Wohlthätigkeit (Ausarbeitung eines im Winter 1893-94 im hiesigen Vereine ,, Solidarität” gehaltenen Vortrages), Druck von Josef Fischer, Krakau 1895.

Statut des Bet- und Unterstützungshauses der deutschen Israeliten in Krakau [1843], Druck von Karl Budweiser und Comp. in Krakau, Krakau 1857.

Sprawozdanie wydziału zawiadowczego towarzystwa wsparcia biednych chtopców starozakonnych pod godtem ,, opiekujcie się synami ubogich” ,, hisaharu bibne aniim ” z zarzqdu funduszów w roku od 1 grudnia 1870 do 1 grudnia 1871., W Drukarni Uniwersytetu Jagiellońskiego pod zarządem K. Mańkowskiego, Kraków 1871.

Sprawozdanie roczne zarządu towarzystwa wsparcia biednych chłopców starozakonnych pod godtem: „, Opiekujcie się synami ubogich” za czas od 1 grudnia 1874 do 1 grudnia 1875, Nakładem Stowarzyszenia, Czcionkami drukarni „Czasu”, Kraków 1875.

Statuten des „,Vereines zur Unterstutzung armer judischer Knaben”/ Statuta Towarzystwa wsparcia biednych chłopców starozakonnych pod godtem ,,Opiekujcie się synami ubogich”, Nakładem towarzystwa. Czcionkami drukarni związkowej pod zarządem A. Szyjewskiego, Kraków 1881.

Dwudzieste trzecie sprawozdanie zarzadu stowarzyszenia Wsparcia Biednych Chłopców Starozakonnych pod godłem ,Opiekujcie się synami ubogich” za czas od 1 Grudnia 1888 do 1 Grudnia 1889, Nakładem Stowarzyszenia, Kraków 1889.

Dwudzieste czwarte sprawozdanie zarzadu Stowarzyszenia Wsparcia Biednych Chtopców Starozakonnych pod godłem ,Opiekujcie się synami ubogich” za czas od 1 Grudnia do 30 Listopada 1890., Nakładem Stowarzyszenia, Kraków 1890.

Dwudzieste piąte sprawozdanie zarządu Stowarzyszenia wsparcia biednych chłopców starozakonnych pod godtem ,opiekujcie sie synami ubogich” za czas od 1-go Grudnia 1890 do 30-go Listopada 1891, Nakładem Stowarzyszenia - Drukiem Józefa Fischera, Kraków 1891.

Dwudzieste siódme sprawozdanie zarządu Stowarzyszenia wsparcia biednych chłopców starozakonnych pod godtem ,opiekujcie się synami ubogich” za czas od 1-go Grudnia 1892 do 30-go Listopada 1893, Nakładem Stowarzyszenia - Drukiem Józefa Fischera, Kraków 1893.

Dwudzieste ósme sprawozdanie zarządu Stowarzyszenia biednych chtopców starozakonnych pod godtem ,opiekujcie się synami ubogich” za czas od 1-go Grudnia 1893 do 30-go Listopada 1894, Nakładem Stowarzyszenia - Drukiem Józefa Fischera, Kraków 1894.

Dwudzieste dziewiąte sprawozdanie zarządu Stowarzyszenia wsparcia biednych chtopców starozakonnych pod godłem ,opiekujcie się synami ubogich” za czas od 1-go grudnia 1894 do 30-go listopada 1895, Nakładem Stowarzyszenia - Drukiem Józefa Fischera, Kraków 1895.

Trzydzieste sprawozdanie zarządu stowarzyszenia wsparcia biednych chłopców starozakonnych pod godtem ,, opiekujcie się synami ubogich” za czas od 1-go grudnia 1895 do 30-go listopada 1896, Nakładem Stowarzyszenia - Drukiem Józefa Fischera, Kraków 1896.

Trzydziesto-siódme sprawozdanie zarząu stowarzyszenia wsparcia biednych chłopców starozakonnych pod godtem ,opiekujcie się synami ubogich” za czas od 1-go stycznia 1903 do 31-go grudnia 1903, Nakładem Stowarzyszenia - Drukiem Józefa Fischera, Kraków 1904.

Sprawozdanie z działalności Zachodnio-Małopolskiego Związu Towarzystw Opieki nad Sierotami Żydowskimi w Krakowie. Czerwiec 1933, Kraków 1933. 


\title{
Prasa
}

\author{
„Czas” (Kraków) \\ „Dziennik Poznański” (Poznań) \\ „Gazeta Polska” (Warszawa) \\ „Głos Narodu” (Kraków) \\ „Der Israelit” (Lwów) \\ „Izraelita” (Warszawa) \\ „Die Neuzeit” (Wiedeń) \\ „Nowa Reforma” (Kraków) \\ „Nowy Dziennik” (Kraków) \\ „Ojczyzna” (Lwów) \\ „Sprawiedliwość. Die Gerechtigkeit” (Kraków)
}

\section{Opracowania}

Biberstein A., Zagłada Żydów w Krakowie, Wydawnictwo Literackie, Kraków 2001.

Kozińska-Witt H., Die Krakauer Jüdische Reformgemeinde 1864-1874, Peter Lang, Frankfurt am Main 1999.

Kozińska-Witt H., Miłosierdzie gminy? - niepublikowany referat wygłoszony na konferencji „Żydzi w Galicji/Jews in Galicia” (8-9 czerwca 2017).

Łapot M., Opieka nad żydowskim dzieckiem sierocym $w$ Małopolsce Zachodniej w okresie międzywojennym, „Prace Naukowe Akademii Jana Długosza. Pedagogika” 2005, nr 14, s. 49-79.

Meissner-Łozińska J., Placówki opieki nad dzieckiem w Krakowie w okresie autonomii galicyjskiej [w:] Galicja i jej dziedzictwo, t. 16: Opieka nad dzieckiem w Galicji, red. A. Meissner, Wydawnictwo Uniwersytetu Rzeszowskiego, Rzeszów 2002, s. 94-113.

Szczygieł M., Formy opieki nad sierotami żydowskimi w Rzeczypospolitej Polskiej w latach 1918-1939 (wybrane przyklady i aspekty), „Prace Naukowe Akademii Jana Długosza. Pedagogika" 2005, nr 15, s. 173-185.

Śliż M., „Fundacja na stypendia dla biednych uczniów Wydziału Lekarskiego Akademii Jagiellońskiej bł. p. Leona Szancera” i jej twórca, „Archiwum Historii i Filozofii Medycyny" 2004, t. LXVII, nr 2-4, s. 139-149.

Żbikowski A., Żydzi krakowscy $i$ ich gmina w latach 1869-1919, Wydawnictwo DiG, Warszawa 1994. 